\title{
Social Acceleration and the Climate Crisis: On the Production of Mental Distress and the Stimulation of the Resourceful Feeling of Anger
}

\author{
Aceleración social y crisis climática: sobre la producción de sufrimiento mental y la \\ estimulación del inventivo sentimiento de enojo
}

\section{Aceleração social e crise climática: sobre a produção de sofrimento mental e a estimulação do engenhoso sentimento de raiva}

Anders Petersen *

\section{* AALBORG UNIVERSITY}

\begin{abstract}
:
In this article I address the interrelation between social acceleration and the climate crisis. I more specifically ask how changed social practices in light of social acceleration and the climate crisis are possible by focussing on two aspects: How the incessant social acceleration of contemporary society is both supporting the formation of the underlying problems connected with the climate crisis as well as hindering efficient collective and individual action on the climate crisis. And the unfolding climate crisis is contributing to the development of specific forms of mental malaises that are only worsened due to the acceleration of this crisis. I end by examining how the feeling of anger can be understood as a social motor for changing our social practices and thus serve as a vector of critique against the sources of social acceleration and ultimately of some of the vital components propelling climate change.
\end{abstract}

Keywords: Social acceleration; Climate crisis; Mental distress; feelings of anger.

\section{Resumen:}

En este artículo se aborda la interrelación entre aceleración social y crisis climática. Más específicamente, se pregunta cómo el cambio de prácticas sociales es posible a la luz de la aceleración social y la crisis climática, enfocando el argumento en dos aspectos: cómo la aceleración incesante de la sociedad contemporánea apoya la 
formación de los problemas subyacentes conectados con la crisis climática, a la vez que obstaculiza acciones colectivas e individuales eficientes sobre dicha crisis. Y la crisis climática que se despliega contribuye al desarrollo de formas específicas de enfermedad mental que solo empeoran gracias a la aceleración de la crisis. Finalmente, se examina cómo el sentimiento de enojo puede ser entendido como un motor social para cambiar nuestras prácticas sociales y así servir como vector crítico contra las fuentes de aceleración social, y en último caso de los componentes vitales que impulsan el cambio climático.

Palabras clave: aceleración social; crisis climática; sufrimiento mental; sentimientos de enojo.

\section{Resumo:}

Neste artigo se aborda a interrelação entre aceleração social e crise climática. Especificamente, se pergunta como as mudanças das práticas sociais são possíveis à luz da aceleração social e da crise climática. A argumentação se debruça em duas vertentes: como a incessante aceleração da sociedade contemporânea favorece a formação de problemas subjacentes e conectados à crise climática, bem como entrava ações coletivas e individuais eficazes acerca dela. Desta maneira, a atual crise climática também contribui ao desenvolvimento de formas específicas de sofrimento psíquico que só pioram devido à da aceleração da crise. Finalmente, se indaga acerca de como o sentimento de raiva podem tornar-se um motor para as mudanças das nossas práticas sociais; e servir assim de vetor crítico contra as fontes da aceleração social e, em última instância, de alguns dos componentes vitais que impulsionam a mudança climática.

Palavras-chave: aceleração social; crise climática; sofrimento psíquico; sentimentos de raiva.

Received: October 20, 2020

Accepted: December 10, 2020 


\section{Introduction}

We find ourselves in a crisis. Perhaps more so now than in the decades succeeding World War II, people around the world are put to the test. The Covid-19 pandemic has dramatically altered our lives and transformed how we perceive and practice work, fun, health, everyday life, social interactions, and participation in cultural and sporting events, among other things, and it has put a strain on our understandings of what democracy and freedom entail. We are tested constantly, both for Covid-19 and for our lockdown endurance, and this is taking its toll. People are losing their lives, livelihoods, everyday face-to-face interactions and - to put it brutally - their minds. As new research from Denmark has shown, levels of mental distress rose significantly during the country's January-March 2021 lockdown, causing more people to feel stressed. ${ }^{1}$ This is hardly surprising, especially when one takes into consideration the abrupt disruption of what Georg Simmel called "sociability" - that is, people's need to engage in regular face-to-face interactions. ${ }^{2}$ Here, online interaction does not cut it. As Randall Collins recently stated, when people are deprived of embodied interactions due to the pandemic, "we can expect they will be more depressed, less energetic, feel less solidarity with other people, [and] become more anxious, distrustful, and sometimes hostile". ${ }^{3}$

The negative consequences of this crisis are thus dire. However, it, too, shall pass. Without neglecting the anguishes of the Covid-19 crisis or downplaying its long-term cultural, economic, and human consequences, we must be aware that the societal ills of another crisis, which is currently more or less ignored, in many ways surmount the problems created by the virus. I am, of course, talking about the climate crisis.

The climate crisis is not going away. Carbon dioxide is, to a larger and larger extent, pumped into the air and causing extreme devastation. There is no vaccine for this crisis, nor can we rely on a technological quick fix, although creative businesses are trying to invent technology that can magically relieve us from melting ice caps,

1 See "HOPE - How Democracies Cope with COVID19 A Data-Driven Approach", consulted in May 2021, available at https://hope-project.dk/\#/.

2 Georg Simmel, “The Sociology of Sociability”, American Journal of Sociology 55, no. 3 (1949): 254-261.

3 Randall Collins, "Social Distancing as a Critical Test of the Micro-Sociology of Solidarity", American Journal of Cultural Sociology 8 (2020): 496. 
overheating oceans and more frequent fires and storms. However, by all accounts, the climate crisis is only getting worse. Without sounding defeatist, it is fair to say that we find ourselves, as species, in a hitherto unseen predicament that endangers our civilizations as well as the survival of the planet as a habitable place for human beings. That is not to say though that we cannot try to ameliorate the crisis's most ominous consequences by changing our social practices. Indeed, we must act differently and lead the way to a sustainable transition - but how, and on what basis? These are the most pertinent and decisive questions to engage with today. Of course, they cannot be stringently answered by one discipline alone - we are in desperate need of collaboration among all the sciences, especially the social sciences and the humanities. As I am not able to cover all of these academic areas here, therefore I will confine myself to some of the perspectives that sociology has to offer.

In this article, my aims are twofold. First, I would like to show that some of the problematic aspects of acting on the current climate crisis (and hence constructing new social practices that support society's sustainable transformation) can be partly attributed to the phenomenon of social acceleration - that is, the incessant social acceleration of contemporary society both supports the formation of the climate crisis's underlying problems and hinders efficient collective and individual action to address them. Second, I will show that the climate crisis is contributing to the development of specific mental malaises that are only worsened by its acceleration. I will end by examining how anger can be understood as a motor for changing our social practices and thus serve as a vector of critique against the sources of social acceleration and, ultimately, against some of the critical agents propelling climate change. Before continuing, I would like to stress that this article purposefully straddles the analytical and the polemical, entailing, especially in its last section, critical perspectives that are not hidden but rather finely knitted into the analysis.

\section{Social acceleration as societal condition}

According to Ulrich Beck and Wolfgang Bonss, ${ }^{4}$ one of the fundamental undertakings of sociology is to diagnose the times. ${ }^{5}$ In fact, it is possible to make the claim that sociology, on an overall level, has always had the ambition of trying to diagnose

4 Ulrick Beck and Wolfgang Bonss, Die Modernisierung der Moderne (Frankfurt am Main: Suhrkamp, 2001), 63. 
society's essential character. ${ }^{6}$ That claim is not hard to support. Sociology's founding fathers all undertook diagnoses of their times; more specifically, they analysed the transition from traditional society to modern society and its implications. Karl Marx, Georg Simmel, Emile Durkheim, and Max Weber all focused on the wide-ranging consequences of this rupture and the malaises it brought about: anomie, alienation, the "iron cage" of modern rationality and the tragedy of culture. In relation to diagnoses of contemporary society, the founding fathers' concepts and analyses are, of course, no longer entirely adequate. As many authors have reported, we have moved on to a new historical epoch that requires new understandings and concepts to adequately understand this transformation. A wide range of names has been given to this epoch, including post-modernity, ${ }^{7}$ hypermodernity, ${ }^{8}$ liquid modernity, ${ }^{9}$ and late modernity, ${ }^{10}$ to identify just a few. Whatever conceptualisation one prefers, the ideas used to capture the essential character of this epoch have changed, and so have the malaises that encapsulate our era.

For the sake of this article, the diagnosis of the times offered by German sociologist Hartmut Rosa is of utmost importance. There is no doubt that he has most significantly and with the greatest impact analysed our epoch - late modernity - as defined by a central dynamic, namely social acceleration. In his Alienation and Acceleration, Rosa constructed a "systematic theory and a sound concept of social acceleration"11 that showed how social acceleration, by force of three distinct categories - technological, social change and pace of life -, has become the most important social phenomenon in contemporary society. A detailed description of the elements of the theory is not needed here, nor is it paramount to give an account of its drivers. What is pertinent, however, is addressing Rosa's main claim that incessant social acceleration in contemporary society - the formation of a high-speed society generates different forms of alienation.

5 The other two main tasks are the theoretical construction of concepts and the empirical testing of theoretical assumptions.

6 Klaus Lichtblau, "Sociology and the Diagnosis of the Times, or: the Reflexivity of Modernity", Theory, Culture and Society 12, no. 1 (1995): 25-52.

7 Jean-Francois Lyotard, La condition postmoderne: Rapport sur le savoir (Paris: Éditions de Minuit, 1981).

8 Gilles Lipovetsky, Hypermodern Times (Cambridge: Polity Press, 2005).

9 Zygmunt Bauman Liquid Modernity (Cambridge: Polity Press, 2000).

10 Anthony Giddens. Modernity and Self-Identity: Self and Society in the Late Modern Age (Cambridge: Polity Press, 1991).

11 Hartmut Rosa, Acceleration and Alienation (Malmø: NSU-Press, 2010), 14. 
As a critical theorist, Rosa thus followed in Marx's footsteps when he pinpointed alienation as the most significant social pathology in contemporary society. As Rosa made clear, there are various elements of alienation that are associated with human beings experiencing alienation from space, things, our actions, time, and ourselves and others, ${ }^{12}$ but he concluded with a significant distinction: "What we are alienated from through the dictates of speed, I have argued, is not our unchangeable or unalienable inner being, but our capacity for the appropriation of the world". ${ }^{13}$

The dictates of speed have thus not shattered our capacity for change but blunted our capacity to be at one with the world. We are alienated from the world because we have rendered it mute, as Rosa argued in a later book. ${ }^{14}$ The world is mute because we are "structurally compelled (from without) and culturally driven (from within) to turn the world into a point of aggression". ${ }^{15}$ The world has been throughout the historical epoch of modernity and methodically fine-tuned in late modernity - turned into something we control, exploit, attain, master, and thereby make into something useful for our benefits alone. As Theodor W. Adorno and Max Horkheimer stipulated and argued for in The Dialectic of Enligthement, the world is gradually being defined by the structurally and culturally imposed elements of instrumentalisation, which are primarily driven by a wholesale faith in the mechanisms of capitalism and the wonders of a market economy that seem to have become justifiable ends in themselves. ${ }^{16}$

Coming from the tradition of critical theory, Rosa is compelled not only to diagnose the predicaments of contemporary society and direct attention to its embedded social pathologies, but also to develop solutions. He suggested that one such solution lies in the concept of resonance, which could mitigate the problems of social acceleration and, thereby, address the problems of alienation. ${ }^{17}$ In Resonance A sociology of our relationship to the world, Rosa explored the concept of resonance as remaining open to the world, being present and engaged and thereby being

12 Ibid., 83-97.

13 Ibid., 98.

14 Hartmut Rosa, The Uncontrollability of the World (Cambridge: Polity Press, 2020).

15 Ibid., 14.

16 Theodor W. Adorno and Max Horkheimer, Dialectic of Enlightenment (New York: Verso Books, 1997).

17 Hartmut Rosa, Resonance. A Sociology of the Relationship to the World. (Cambridge: Polity Press, 2019): 1. 
receptive to the fact that intersubjective encounters with people and things can alter and transform us. It is in this mode, Rosa stated, that the subject becomes capable of appropriating the world in a way that transforms the self's essence through connection with things and other persons. ${ }^{18}$ Resonance, in short, is therefore a key to unmuting the world and emancipating people from alienation.

In order to substantiate his argument, Rosa analysed various spheres and axes of resonance, one of which was nature. Nature, he demonstrated, has always been understood as a central sphere of resonance in modernity. However, in modern times, it has by and large lost that status and has instead been framed in a context of aggression and perceived as something we should conquer, resulting in it being an abstract category from which people are, to a very large extent, alienated. We are in a situation, Rosa wrote, in which "the idea of a meaningful voice of nature simply does not make sense", ${ }^{19}$ thereby hampering the possibility of resonance and strengthening the comprehension of nature as something we can exploit.

Without the possibility of creating a resonant relationship with nature that is rooted in the terms of sustainable transformation, altering social practices towards it becomes hard, if not impossible, particularly given that the climate crisis is the result of our high-speed destruction of nature (deforestation, overfishing, impoverishing soil as a result of overuse, etc.) and of natural habitats for humans and non-humans alike. I will, however, add that Rosa's reluctance to perceive deceleration as a solution to acceleration and alienation ${ }^{20}$ is misguided when it comes to the compulsory changing of social practices in relation to the climate crisis. In order to back up my claim, I will start by directing attention to one of the pivotal human consequences of the ongoing destruction of nature, namely how it produces mental distress.

\section{Social acceleration, climate change and mental distress}

As argued above, the mere speed of constant social acceleration and alienation have muted nature. In contemporary high-speed society, nature no longer has a distinct voice that clearly resonates with the majority of people. In other words, our social practices are not compatible with the establishment of a sustainable association with

18 Ibid., 17-43.

19 Ibid., 273.

20 Ibid., 1-2. 
nature. What is often called the Anthropocene ${ }^{21}$ - a term that first and foremost designates a geological epoch dating from the commencement of extended human influence on Earth's geology and ecosystems - is a pivotal conceptualisation in relation to climate change, as it underlines a well-established scientific fact: the climate crisis is manmade. Indeed, only hardcore sceptics believe that climate change is due to "naturally occurring transformations in ecosystems" or "haphazard fluctuations" that we cannot do anything about. The rest of us know by now that people's actions in the Anthropocene have not only produced climate change but are accelerating it.

As we produce and reproduce this rupture with nature and thereby produce and reproduce the devastating consequences of the climate crisis, we are also supporting the ongoing creation of fundamental losses - that is, our continuous destruction of the planet's ecosystems creates losses that are irreversible. Indeed, the rapid extinction of various plants and animals, the destruction of habitats and mutations to pollinators, among other consequences, are irrevocable. However, these losses also, as I will show in what follows, have specific mental impacts on people, making the concept of loss key to the understanding of this human predicament. The question, therefore, is how we are able to understand loss.

As Swiss sociologist Nina Jakoby has argued, there are several categories of loss, but we can break the idea into two dimensions: personhood/artefact and materiality/immateriality. ${ }^{22}$ By making this distinction, we are furthermore able to sort loss experiences into three general categories: “(a) relationship loss (personal, animal), (b) status loss (way of being, such as health, or job), and (c) (im)material object loss (e.g., artefacts, places, ideals)." ${ }^{23}$

It is important to stipulate that each of these experiences of loss is connected to specific emotional responses, i.e., the loss of status can lead to the emergence of frustration, and the loss of a loved one is most often followed by grief. The loss of nature discussed here is clearly within the realm of the last category. Further, as I will specify, the loss of nature that is driven by rapid social acceleration and that triggers a lack of resonance with nature produces the emotional responses of mental distress. In

21 Paul. J. Crutzen and Eugene F. Stoermer, "The Anthropocene", Global Change Newsletter 41 (2000): 17-8.

22 Nina R. Jakoby, “The Self and Significant Others: Toward a Sociology of Loss”, Illness, Crisis and Loss 23, no. 2 (2015): 110-28.

23 Ibid., 112. 
viewing the loss this way, I can make more concrete some of the consequences of social acceleration in connection with the climate crisis. More precisely, I will focus on two types of distress that follow the incessant loss of nature: solastalgia and ecological grief.

These are not, of course, the only negative mental responses to the climate crisis. There are intense international discussions about rising climate anxiety, ${ }^{24}$ the impact of the climate crisis on depression, ${ }^{25}$ and the proliferation of climate stress. ${ }^{26} \mathrm{I}$ believe they cover the range of mental distresses caused by the climate crisis in the best and most nuanced manner. They enlighten us as to the porous predicament we find ourselves in while also persuasively identifying the mental consequences of the situation. Yet, in engaging with these phenomena, we also direct attention to some of the difficulties surrounding the societal recognition of mental reactions to the climate crisis.

\section{Solastalgia}

We are indebted to Australian philosopher Glen Albrect for the term "solastalgia". ${ }^{27}$ His work in the Hunter Region of New South Wales, Australia, where the rapid expansion of open-pit coal mining, increasing power station pollution, and general obliteration of natural habitats, made him aware of the relationship between ecosystem distress and human distress. Inspired in particular by Elyne Mitchel, namely that the loss of psychic stability can be instigated when people experience the loss of their earthly roots, Albrect sought a suitable concept to describe the malaises he witnessed in this particular part of his homeland. On the basis of this research, he coined the term solastalgia, which "refers to the pain or distress caused by the loss of, or inability to derive, solace connected to the negatively perceived state of one's home

24 Susan Clayton, "Climate Anxiety: Psychological Responses to Climate Change", Journal of Anxiety Disorders, no. 74 (2020).

25 Haris Majeed and Jonathan Lee, "The Impact of Climate Change on Youth Depression and Mental Health". The Lancet 1, June (2017): 94-95.

26 Joanne Catherine Jordan, "Swimming Alone? The Role of Social Capital in Enhancing Local Resilience to Climate Stress: A Case Study from Bangladesh", Climate and Development 7, no. 2 (2015): 110-123.

27 Glenn Albrecht, "Solastalgia: A New Concept in Human Health and Identity", PAN (Philosophy, Activism, Nature), no. 3. (2005). 
environment. Solastalgia exists when there is the lived experience of the physical desolation of home". ${ }^{28}$

The term has its origins in the concepts of solace and desolation. When consulting the dictionary, one finds that solace is derived from solari and solacium, and has meanings connected to the alleviation of distress or the provision of comfort or consolation in the face of distressing events. Desolation, on the other hand, "has its origins in 'desolare' with meanings connected to abandonment and loneliness... In addition, the concept has been constructed such that it has a ghost reference or structural similarity to nostalgia so that a place reference is imbedded". ${ }^{29}$

In my view, what makes solastalgia such a durable and intriguing concept is its empirical applicability, scholastic scaffolding, and intuitive rightness. ${ }^{30}$ Whereas Albrecht showed how to apply it empirically in a pertinent way and in great detail, I will here focus on the latter because, if we relate to the concept's focus on loss, desolation, and lack of possibilities, we can understand why the climate crisis produces the mental distress of solastalgia and why, by all accounts, it will continue to do so. If we take the concept seriously and accept that what we are currently witnessing is, in many ways, a grand-scale expansion of what Albrecht addressed, we are informed that droughts, flooding, overheating and the overwhelming disappearance of stable dwellings and habitats, and we see that homes around the world are not only being lost but the possibility of finding solace is as well. When loss is irreversible, solace is left out of the equation. How can solace be found in something that is disappearing - and disappearing at such an increasingly rapid pace?

Though Albrecht did not emphasise the acceleration of losses, I believe it is worth underscoring. Speed is a matter of concern here, and time is of the essence. It is a fact that the acceleration of the climate crisis is self-reinforcing in that the ongoing destruction of nature increasingly has devastating effects on people. Floods, droughts, fires, and other harmful events increase every year, ultimately leading us to question the stable positioning of what we call home. The increasing insecurity of this otherwise vital facet of people's lives - people's homes are often seen as safe places

28 Glenn Albrecht et al., "Solastalgia: The Distress Caused by Environmental Change", Australian Psychiatry 15 (2007): 96.

29 Glenn Albrecht, "Solastalgia: A New Concept in Human Health and Identity", 45.

30 Anders Petersen, "Når klimaets tilstand gør ondt: Følelser i klimakrisens tid [When the Conditions of the Climate Are Hurting: Feelings in the Age of the Climate Crisis]", in Det går til Helvete. Eller?: Om kjcerlighet, sorg og raseri i natur- og klimakrisens tid, K. I. Bjørlykhaug and A. Johan Vetlesen eds. (Oslo: Dinamo Forlag, 2020). 
where they can relax - is detrimental to the feeling of security. Hence, on a planet where more and more areas are becoming impossible to live in and the possibility of recovering what is lost is not only difficult but outright impossible, a central component of human safety is also being lost. Thus, when finding solace in the possibility of reversing the situation is not possible, mental distress is surely worsened.

What can be done? As mentioned, Albrecht highlighted nostalgia as a key component in his conceptualisation of solastalgia. While nostalgia is no longer construed as a mental illness, as was the case many decades ago, it still refers to an upsetting yearning for better times. As Fred Davies once wrote, "Nostalgia is more a crepuscular emotion. It takes hold when the dark of impending change is seen to be encroaching, although not so fast as to make a monster loom where but a moment ago stood a coat tree". ${ }^{31}$

However, even though the emotion of nostalgia is understandable and perhaps even desirable at times, the positive valorisation of the past it connotes does not do much good when it comes to the climate crisis. Whereas a nostalgic perspective on the past can ignite political and social movements that actively work towards a societal return to the 1950 s (we see this all too clearly across Europe), this type of return is not possible when it comes to the climate crisis. We cannot retrieve what is being lost. There is no turning back the clock when it comes to extinct species, the creation of unlivable areas due to increased water levels, the wastelands produced by the expansion of mining and the complete disappearance of landscapes due to heavy pollution. Therefore, as Albrecht argued, nostalgia in relation to the climate crisis can come with feelings of loneliness and powerlessness, which only add to the experience of mental distress. When people are placed in genuinely unalterable situations, nostalgia about a past that is impossible to retrieve may add insult to injury and exasperate mental suffering. Thus, as I will argue later, in order to tackle this situation, the societal embedding of emotions such as anger is needed.

\section{Solastalgia: A mental illness?}


One should always be careful when developing new concepts that frame mental suffering as an illness. As has clearly been the case in recent years, the emergence of a diagnostic culture ${ }^{32}$ has meant that more and more mental reactions to societal problems are classified as mental illnesses - that is, there has been a steady increase in the amount of people diagnosed with mental illnesses, such as anxiety, depression and ADHD, and one could argue that the threshold for being diagnosed as such has widened. The obvious question in relation to solastalgia is therefore whether we should perceive it as a mental illness that could find its way into one of the diagnostic manuals, such as the DSM. Albrecht seems to have made the argument that we ought to - potentially - make room for solastalgia in the diagnostic manuals. However, as Seamus MacSuibhne has forcefully argued, several flags should be raised here, the most pivotal being that solastalgia should be understood as a social rather than a mental form of suffering and that we should thus treat it socio-politically rather than medically. ${ }^{33}$

Solastalgia is not an individual health problem. There is no doubt about the fact that during the last four decades or so, we have witnessed a process of relentless individualisation of mental malaises: anxiety, depression, ADHD, autism, etcetera. ${ }^{34}$ However, going down this road is not only a dangerous impasse that we need to be aware of, it is a process we should actively counter. And solastalgia precisely directs attention to the structurally imposed problems of the ongoing process of ruthlessly exploiting nature, and it cannot be reduced to an individual problem that needs to be addressed individually. That is not to say, however, that individuals suffering from solastalgia are not in need of focused attention or care. We would do a disservice to the problem of solastalgia if we were to disconnect it from the actual and painful suffering people endure due to the climate crisis. Instead of writing it off as a socially repairable problem, we should pay even more attention to it going forward, as human suffering resulting from the climate crisis will likely increase.

\section{Ecological grief}

32 Svend Brinkamnn, Diagnostic Cultures (London: Routledge, 2016).

33 Seamus P. MacSuibhne, "What Makes "a New Mental Illness"?: The Cases of Solastalgia and Hubris Syndrome", Cosmos and History: The Journal of Natural and Social Philosophy 5, no. 2 (2009): 223.

34 Nikolas Rose, Our Psychiatric Future (Cambridge: Polity Press 2019). 
What is "ecological grief" and how does this description relate to the mental suffering caused by the climate crisis? To answer this, we must start by looking at the phenomenon of grief itself.

Most people will, at some point, lose a significant other and therefore experience grief as the painfulness of the permanent absence of another person. ${ }^{35} \mathrm{In}$ that respect, grief is an emotion related to absence that arises when we realise that someone near and dear is lost. Within the confines of this understanding, loss is often related to someone's death or leave, such as a significant other. The absolute absence of another person automatically generates the experience of what Jean-Paul Sartre called a 'concrete nothingness', ${ }^{36}$ by which he meant the existential realisation that someone is missing for good. Pierre, in Sartre's famous example, is simply not there anymore and will, in fact, never return.

Second, with the help of David Hume, we can state that grief should be perceived as a basic human condition. Alternatively, we can perhaps understand it by claiming that it is a basic human emotion. In A Treatise on Human Nature, Hume considered grief (alongside fear, hope, and joy) to be one of the basic human emotions - what he referred to as "direct passions". ${ }^{37}$ For my purposes here, what is important is Hume's proclamation that grief is a human emotion "writ large" in all its overwhelming effects. ${ }^{38}$ It is also important to state that most people will experience grief at some point in their lives when someone dies or leaves.

It is beyond the scope of this article to discuss all the implications of these statements, so I will limit myself to approaching ecological grief as a human emotion of permanent absence by asking the following questions: what triggers this emotion, and how is it expressed? When it comes to the former, one quickly realises that very little research has considered ecological grief as an area of formal scientific inquiry. When research has been undertaken, the triggers of ecological grief are presented as rather obvious, namely the immediate loss of nature, habitats, and inhabitable places. ${ }^{39}$

35 Anders Petersen and Michael H. Jacobsen, "Grief - The Painfulness of Permanent Human Absence", in Emotions, Everyday Life and Sociology, Michael H. Jacobsen ed. (London: Routledge, 2018), 191-208.

36 Jean-Paul Sartre, Being and Nothingness, (London: Philosophical Library, 1956).

37 David Hume, A Treatise of Human Nature (Oxford: Oxford University Press, 1978).

38 It might not be the case, I know, that grief also qualifies as what some emotion researchers call a "basic emotion", but it is nevertheless my contention that this understanding is valid and useful for the purposes of this article.

39 Ashlee Cunsolo and Ellis, Neville R, "Ecological grief as a mental health response to climate change-related loss", Nature Climate Change 8, no. 4 (2018): 275-81. 
Make no mistake: this development is, by itself, worth grieving, and it evokes responses such as sadness, pain, yearning, and worry. However, I would like to present a more elaborate answer: what is being lost are future possibilities. In that respect, ecological grief is also about the anticipation of possibilities lost, which echoes what Erich Lindemann coined in 1944 as “anticipatory grief”. In Lindemann's thinking, anticipatory grief emerges as a consequence of a specific type of separation: that resulting from a likely death. As Lindemann pointed out when explaining the concept:

The patient is so concerned with her adjustment after the potential death of father or son that she goes through all the phases of grief - depression, heightened preoccupation with the departed, a review of all the forms of death that might befall him, and anticipation of the modes of readjustment which might be necessitated by it. ${ }^{40}$

It is obvious that the form of separation that triggers anticipatory grief is twofold. First, there is the actual physical separation: sending one's son, husband or father off to war. Second, there is a powerful emotional separation: the raging uncertainties, feelings of insecurity and fear of death that follow such a departure. It is particularly the latter that produces the grief responses mentioned by Lindemann.

Ecological grief is also triggered by the potentialities of death captured by the concept of anticipatory grief. Yet, there seems to be one more layer to the phenomenon of ecological grief, which we can elucidate and capture by calling it “deep ecological grief". For the loss of nature - melting ice caps, rising sea levels, deforestation and other effects of climate change - not only reduces the possibilities of creating a good immediate future or making us grieve for what will potentially come; rather, the loss profoundly questions our entire ability to secure a good and positive future for the generations to come. The depth of this grief, then, is activated by the permanent absence of something as vital to people as their embedded ability and inclination to develop a better and more accommodating future for their children and grandchildren than the one they foresaw for themselves growing up. The presence

40 Erich Lindemann, “The Symptomatology and Management of Acute Grief”, American Journal of Psychiatry 101 (1944): 142. 
of this aggravating emotion focuses our attention on the ways in which this form of deep ecological grief may be expressed.

In order to illuminate this concept more clearly, I will draw on the phenomenologically informed research on grief. Here, it is common to refer to firstperson experiences of bereavement as losing part of one's own body, thereby reflecting the immense pain of the loss of a significant other. ${ }^{41}$ For example, as Thomas Fuchs wrote in an important article:

To a certain extent, bereavement may thus be regarded as analogous to a bodily mutilation or even amputation. This may be expressed in statements of bereaved individuals such as: "as if my inside had been torn out and left a terrible wound" the lost one has been "cut off", "as if half of myself was missing", or similar. ${ }^{42}$

If we relate this description of grief to deep ecological grief, the following questions arise: do we lose part of ourselves when vital parts of nature are lost? Are the consequences of the climate crisis in some sense mutilating and amputating us? The most plausible answer to these questions is yes, and this is exactly what is rooted in the concept of deep ecological grief because an amputation is an irreversible occurrence. While one can try to replace a human limb with a plastic or metal device, one can never replace lost parts of nature. Melted ice caps will not come back, and extinct species will not magically reappear. Therefore, deep ecological grief can best be understood as mourning the amputation of parts of nature that ensured a good future for generations to come.

Furthermore, the pace of the mutilation of nature makes deep ecological grief even more salient and significant. In a socially accelerated world in which the climate crisis is also accelerating, one might expect a significant proliferation of this type of mental suffering in the near future. However, that is not to say that this type of suffering is recognised in contemporary society. On the contrary, one could argue that it is not.

41 Matthew Ratcliffe, "Grief and Phantom Limbs: A Phenomenological Comparison” (2018), retrieved in February 2021, available at https://www.researchgate.net/profile/Matthew_Ratcliffe2/publication/ 332282215_Grief_and_phantom_limbs/links/5d29c8f6a6fdcc2462daf1f1/Grief-and-phantom-limbs.pdf 42 Thomas Fuchs, "Presence in Absence. The Ambiguous Phenomenology of Grief", Phenomenological Cognitive Science 17 (2018): 46. 


\section{Deep ecological grief as a form of disenfranchised grief}

As Ashlee Consolo and Karen Landman ${ }^{43}$ wrote, the general lack of recognition of ecological grief in contemporary society is widespread and deeply concerning. It is as though the underemphasising of this type of mental suffering has led to the sociopolitical rejection of the problem. Ecological grief is not taken seriously because it does not fit the general societal expectations of what is grievable. In many respects, the grievability of losses of nature has not found its way into the socio-political vernacular of what we ought to mourn. The same goes, of course, when it comes to deep ecological grief. One way to understand this seemingly lack of acceptability, appropriateness, and normative legitimacy when it comes to deep ecological grief is to make use of the concept of "disenfranchised grief". American gerontologist Kenneth J. Doka coined the term ${ }^{44}$ and defined it in the following manner:

The concept of disenfranchised grief recognizes that societies have sets of norms - in effect "grieving rules" - that attempt to specify who, when, where, how, how long, and for whom people should grieve. These grieving rules may be codified as personal policies (...) Such policies reflect the fact that each society defines who has a legitimate right to grieve, and these rights correspond to relationships, primarily familial, that are socially recognised and sanctioned. ${ }^{45}$

It is possible to question whether contemporary society's grieving rules have created space for the phenomenon of deep ecological grief. It is moreover possible to problematise whether grief functions in these binary codes, and when it comes to deep ecological grief, one either grieves or not. It nonetheless seems obvious, as Patricia Robson and Tony Walter emphasise, ${ }^{46}$ that every society has certain "grief hierarchies" that determine the kinds of grief that are more legitimate than others. Deep ecological grief is ranked low in these hierarchies. However, in relation to the potential societal recognition of deep ecological grief, the good news is that these

43 Ahslee Cunsolo and Karen Landman eds., Mourning Nature. Hope at The Heart of Ecological Loss and Grief (Montreal: McGill-Queen's University Press, 2017).

44 Kenneth J. Doka, Disenfranchised Grief: Recognizing Hidden Sorrow (Lexington MA: Lexington Books/D. C. Heath \& Co., 1989).

45 Kenneth J. Doka "Disenfranchised Grief”, Bereavement Care 18, no. 3 (1999): 37.

46 Patricia Robson and Tony Walter, "Hierarchies of Loss: A Critique of Disenfranchised Grief", Omega 66, no. 2 (2012-2013): 97-119. 
hierarchies are in no way static. They are attuned to the normative structures and development of society, and we can thus hope that political, cultural, social, and economic currents will alter the overall texture of society so that deep ecological grief is taken more seriously.

\section{Anger as a resourceful driver of change and initiator of care}

What, then, can be done? One thing is certain: we must change our social practices if we want to ameliorate the worst consequences of the climate crisis and reduce the mental malaises it causes - and the window of opportunity is closing quickly. We know this - and by "we", I mean the big we. The Intergovernmental Panel on Climate Change created by the United Nations Environment Programme has warned us many times and stipulated the urgency of action in the Paris Agreement. No country, institution, or person is unaffected by this situation. We are all in the same boat, as we often hear. On closer inspection, however, this is not the case.

As Ulrich Beck stated when theorising on the risk society, ${ }^{47}$ we live in a socially stratified order. Although everyone was affected by the implications of the risks he focused on - acid rain, nuclear waste, pesticides in drinking water -, some were better positioned than others to handle and cope with the fallouts. Rich people may not have been able to buy their way out of such predicaments, but they were able to avoid the most ominous circumstances. The same is the case now. For example, at the beginning of March 2020, when the Covid-19 pandemic had just started, The Guardian ran an article headlined "Super-rich jet off to disaster bunkers amid coronavirus outbreak". ${ }^{48}$ The super rich, the article said, were preparing for a long period of self-isolation in conveniently built residences that were able to accommodate them and their staff, doctors and nurses. This was not an anomalous report. Although the pandemic has grounded planes around the world and shut down travel destinations on all continents, some of the world's wealthier people have still

47 Ulrick Beck, The Risk Society (Cambridge: Polity Press, 1992).

48 Rupert Neate, "Super-rich jet off to disaster bunkers amid coronavirus outbreak" (2020), retrieved in October 2020, available at https://www.theguardian.com/world/2020/mar/11/disease-dodgingworried-wealthy-jet-off-to-disaster-bunkers? fbclid=IwAR0BuHhiOTjpQ8XU4iCTDiqHqhBIYCXCLdkLX7yKmMmH0p4J41W1qyVw2sk. 
found their ways to Dubai, Mexico or other sunny spots. Apparently, travel bans do not apply to them.

When it comes to the climate crisis, we are witnessing similar inequalities but on larger scales. As The Independent reported in 2019, the United Nations has warned that we might be witnessing the emergence of a climate apartheid, meaning that "[r]ich people buy their way out of the environmental crisis while poor people suffer". ${ }^{49}$ These are strong words, but perhaps they are necessary. Because the term "climate apartheid" highlights the widening economic gap between rich and poor, the climate crisis might also lead to new forms of social and cultural submission. When specific norms and rules only apply to some people, the control and regulation of others by force is made possible. This certainly applies when it comes to the ways in which the climate crisis affects us. In so many different ways, the rapid development of the climate crisis, and the fact that a small proportion of the world's population is trying to pin the consequences on the rest, should be enough to make us all indignant and outright angry.

As John J. Drummond argued, indignation and anger are related emotions that emerge as responses to social, ethical or moral offences..$^{50}$ Moreover, Drummond suggested, under the right circumstances, they motivate action against the offence. From my perspective, the two feelings are mutually supportive - that is, indignation in relation to accelerating climate change ignites anger. The offence addressed here societal wrongdoings that escalate the climate crisis - should constitute enough reason to motivate substantial individual and collective action, or so one should think. Yet, this is not the case.

In what follows, I am inspired by American sociologist Kari Marie Norgaard thought-provoking analyses to shed light on this conundrum. In her empirical study on how certain feelings lead to a lack of participation in social movements that fight climate change, Norgaard took her point of departure from Arlie R. Hochschild's conceptualisation of emotion work and Evitar Zerubavel's understanding of socially

49 Tom Batchelor, "Climate Apartheid'. Rich people to buy their way out of the environmental crisis while poor suffer, warns UN" (2019), retrieved in October 2020, available at https://www.independent.co.uk/environment/climate-change-crisis-rich-poor-wealth-apartheidenvironment-un-report-a8974231.html.

50 John J. Drummond, “Anger and Indignation", in Emotional Experiences. Ethical and Social Significance, John J. Drummond and Sonia Rinofner-Kreidl eds. (London: Rowman and Littlefield International, 2017), 15-31. 
organised denial. ${ }^{51}$ What baffled Norgaard in her field study on a remote Norwegian village was the fact that people realised that climate change is manmade but that they still did not seem to do anything about it. This passivity could not be explained by ignorance or indifference. Rather, Norgaard contented that a large part of the reluctance to take action was related to the emotional unpleasantness that the climate crisis created and the villagers wanted to deny. The villagers simply found it objectionable to engage in social interaction with others if the content of this interaction revolved around climate change. Hence, they tried to override and sometimes even belittle the issue and thus avoid using its consequences as action coordinates, or they navigated using other coordinates and were in that way steering away from active engagement in finding solutions to the climate crisis.

A large part of the explanation for this apathy or wilful ignorance relies in the fact that denial is culturally necessary if the villagers want to preserve the cohesion of their community, and at the same time, it offers each member of the community an opportunity to individually protect themselves from the emotional distress caused by reflecting about the climate crisis. ${ }^{52}$ As Norgaard noted, the villagers were simply selective when it came to the aspects of the climate crisis they wanted to discuss, and they were equally selective in choosing the interpretive scheme they used to construe the consequences of the climate crisis. As a result, focus was directed away from climate change and towards something else. As Norgaard wrote:

Emotions played a key role in denial, providing much of the reason why people preferred not to think about global warming. Furthermore, the management of unpleasant and "unacceptable" emotions was a central aspect of the process of denial, which in this community was carried out through the use of a cultural stock of strategies and social narratives that were employed to achieve selective attention and perspectival selectivity. ${ }^{53}$

Thus, social relations were not bothered by uncomfortable narratives about climate change. Instead, the villagers' emotional work was one of downplaying the seriousness of the situation rather than motivating themselves to find solutions to the

51 Kari Marie Norgaard, "People Want to Protect Themselves a Little Bit: Emotions, Denial, and Social Movement Nonparticipation”, Sociological Inquiry 76, no. 3 (2006): 375.

52 Ibid., 390.

53 Ibid., 392. 
problem, and thus invoke feelings that could help alter the situation. This, Norgaard concluded, was the result of a collectively produced denial that contributed to the villagers' social distancing from active engagement in resolving the climate crisis and helping avoid its most calamitous consequences. ${ }^{54}$

Here, it is interesting to contemplate the potential ways out of this collective denial and discuss which emotions should instead be activated. As Saffron O'Neil and Sophie Nicholson-Cole have forcefully argued, society's incorporation of fear into people is not a productive means of trying to promote positive engagement in the climate crisis. Indeed, the authors showed how social representations of the climate crisis that are based on fear do not lead to sustainable solutions, nor they create the needed personal engagement in solutions. What is worse, society's subscription to climate fear is counterproductive and leads to an emotional decoupling from the climate crisis. The authors concluded that future research must pursue knowledge of how "a much deeper personal concern and lifestyle engagement with climate change can be encouraged through different methods and strategies of communication". ${ }^{55}$ This knowledge, as Sabine Roeser stressed, definitely entails the engagement of particular feelings, as they "might be the missing link in effective communication of climate change", ${ }^{56}$

The questions remain, however, on which feelings should be addressed and how, when trying to overcome the collective denial of the consequences of the climate crisis. Melissa Moore and Janet Yang have recently claimed that fostering the feeling of eco-guilt is productive when promoting a green transition of society. More specifically, they argue that "environmental communication needs to harness the power of guilt, as a moral emotion, to promote environmental behaviour" ${ }^{27}$ and hence stimulate sustainable social practices. Recently, Nancy Fraser has opted for a more radical solution, arguing eloquently that capitalism has been the main socio-historical driver of climate change and that it shelters a deep-seated ecological contradiction; the only legitimate option we have to thoroughly address the problems of the crisis is to

54 Ibid., 394.

55 Saffron O'Neil and Sophie Nicholson-Cole, “"Fear Won't Do It'. Promoting Positive Engagement with Climate Change through Visual and Iconic Representations", Science Communication 30, no. 3 (2009): 377.

56 Sabine Roeser, "Risk Communication, Public Engagement, and Climate Change: A Role for Emotions", Risk Analysis 32, no. 6 (2012): 1033.

57 Melissa M. Moore and Janet Z. Yang, "Using Eco-Guilt to Motivate Environmental Behavior Change”, Environmental Communication 14, no. 4 (2020), 522-36. 
dismantle capitalism and pave the way for the enactment of a new common sense order. Fraser wrote that "[a]nti-capitalism, therefore, could - indeed, should - become the central organising motif of a new commonsense. Disclosing the links among multiple strands of injustice and irrationality, it represents the key to developing a powerful counter-hegemonic project of eco-societal transformation". ${ }^{58}$ The anticapitalist counter hegemony Fraser called for - which, for her, constitutes the only reliable socio-political pathway to safeguarding the planet - is something she refers to as "eco-socialism". The eco-societal transformation needed requires an overarching structural, political, and economic transformation of society - hence a new political order.

According to Frasers line of thought, only such a societal transformation could lift the veil of climate denial, activate feelings of climate-change engagement and thereby transform people's social practices in an environmentally friendly manner. However, though the arguments offered by Moores and Yangs as well as Fraser are compelling, I believe we could approach the issue of engagement in climate-change action somewhat differently. Instead of pursuing a large-scale transformation of the spirit of capitalism, or nurturing the emotion of moral guilt, we could motivate the green transition of society by stimulating a specific feeling. Thus, I would argue that we could - or even should - communicate the consequences of the climate crisis in a way that triggers a reaction in the form of anger. The proliferation and activation of the anger could serve as an effective agent when trying to dissolve structurally imposed denial and to emotionally engage people in the solutions to the consequences of the climate crisis. Indeed, anger can be perceived as a positive emotion and a motivational force for action. ${ }^{59}$ In that respect, anger is a highly resourceful feeling, not because it is individually embedded but because the causes and consequences of the climate crisis affect us collectively and should anger us.

Here, it is important to note that the collective effervescence of anger is needed. Of course, it is crucial that the anger is targeted in the right way. It would be unproductive, even a significant mistake, to guide the anger towards unsustainable populations living in precarious situations that do not have the means or resources to take care of the environment or nurture nature in a sustainable way. The 58 Nancy Fraser, "Climates of Capital. For a Trans-Environmental Eco-Socialism", New Left Review 127 (2021): 97

59 Ursula Hess, "Anger is a positive emotion", in The positive side of negative emotions, W. G. Parrott ed. (New York: Guilford Press, 2014): 55-75. 
stigmatisation of such groups would create a significant and highly unwarranted societal divide that would harm the purposes of generating collective action and, thus, alter people's social practices. Therefore, anger should be directed towards structurally produced targets, in particular some of the ways of decelerating the destructive losses that we know can be dealt with rather easily - such as reducing emissions in farming or the airline industry which results in further global warming, thus overheating the planet. Where the right socio-structural incentives for doing so are missing, also the emotional engagement in achieving this is undermined.

Moreover, evoking the feeling of anger in relation to climate change could facilitate a sustainable way of creating resonance with nature. Anger about the destruction of nature could help bring about with it a feeling of harmony that results in a resonant relationship and thereby alters the instrumentalisation of nature that we are witnessing. As Rosa ${ }^{60}$ informed us, nature has lost its voice in contemporary society, and that is one of the reasons why no resonant relationship has been possible. In his theory of resonance, however, Rosa tended to neglect so-called negative emotions, circumventing them as part of the solution and only seeing them as part of the problem. Anger, according to Rosa, cannot play a constructive part in the establishment of resonance. I believe this is a mistake. From my perspective, the social ignition of anger is a necessity in order to support the societal building of sustainability. The societal implementation of sustainability, here understood as an ethical ideal and important environmental desiderata that have broad intuitive appeal, ${ }^{61}$ requires a strong emotion such as anger, if it is to succeed. It needs a potent fuel to drive it. In that respect, the societal adoption of anger might even bring about a situation in which the obvious mutual interdependence between humans and humans and humans and nature will resurface at a larger societal scale, ultimately leading nature to retrieve its lost voice, which in many spheres of society is so blatantly absent at the moment. Of course, one could argue, grassroots movements such as Fridays for Future and Extinction Rebellion have already answered the call of nature and angrily struggle for the societal realisation of a sustainable future. They do, though, find themselves in the minority and the spillover effect on the rest of society seems to be marginal. 
However, one thing remains to be addressed. Is the implementation of the abovementioned sustainability in a socially accelerated world possible, or does it require societal deceleration? One reading of Rosa would suggest that deceleration results in socio-cultural and economic setbacks and that the slowing down of the tempo almost automatically amounts to a lack of societal progress. ${ }^{62}$ Yet, one could also argue that Rosa only criticised the social acceleration that is propelled by the logic of capitalist-informed accumulation and growth, and thus leaves the door open for deceleration if it is correctly targeted. I argue for the necessity of the latter. From this perspective, the success for deceleration lies in the acceptance of the fact that sustainable progress has to be understood in other terms and that the rate at which the climate crisis creates mental distress and disastrous consequences related to our ability to inhabit this planet requires a reduction of speed. This, of course, does not mean that the societal and personal instalment of anger is the only means of achieving this, but anger could function as a resourceful driver in making such a transition possible.

\section{Conclusion}

In this article, I have examined how the phenomenon of social acceleration is accountable for some of the problematic aspects of acting to resolve the current climate crisis and how it hinders a sustainable green transformation of society. I have furthermore shown that the climate crisis is creating new forms of mental malaises and that these are only worsened by incessant social acceleration. I have ended on a rather polemical footing, sketching a very rough outline of the potential societal implementation of anger as a social motor for changing our predicament. Concerning the latter, one might find this to be a rather mechanical view of society. However, I do not claim that the installation of anger should be a technocratic endeavour. Rather, it calls for democratic deliberation and hence to be perceived as the conceivable outcome of a process of enlightenment.

On a final note, I would like to call for more research on this important area, which could perhaps benefit from engaging more thoroughly with the concept of care. In recent years, thinkers such as Fraser have directed attention to the misrecognition 
of the kinds of care that women mostly undertake - that is, childbearing and other forms of domestic labour - due to how capitalism has undervalued them. ${ }^{63}$ Numerous authors writing together as The Care Collective took this analysis a step further and pointed out that the climate crisis is yet another consequence of the general tendency to undervalue care, namely care towards the natural world. ${ }^{64}$ If, as they argued, care in a high-speed society preoccupied with instrumentalising capitalism is perceived as a sign of weakness, it comes as no surprise that care for nature is perceived in the same way. Thus, we have to alter our perceptions of what interpersonal care and interspecies care consist of, thereby promoting the value of care, and we must furthermore make this concept the organising principle on each and every scale of life, be it individual, interpersonal, or political. ${ }^{65}$ Seen in this light, the need for strengthened theoretical and empirical work on care becomes obvious - perhaps in conjunction with the line of reasoning I have presented here. If getting angry about the offences committed against nature, which support the acceleration of the climate crisis, then action not only entails putting an end to these offences but also taking care of nature in a new way. In this context, anger becomes synonymous with care and, hence, helps to promote feelings of nurture and responsibility. Just imagine if, by feeling angry and doing something about the ongoing destruction of nature, were to become new ways for people to show they care. Anger would not be such a bad feeling in that event.

63 Nancy Fraser. "Contradictions of Capital and Care”. New Left Review, no. 100 (2016), 99-117. 64 The Care Collective. The Care Manifesto. The Politics of Interdependence. (New York: Verso, 2020). 


\section{Bibliographical References}

Adorno, Theodor W. and Max Horkheimer. Dialectic of Enlightenment. New York: Verso Books, 1997.

Albrecht, Glenn. "Solastalgia: A New Concept in Human Health and Identity". PAN (Philosophy, Activism, Nature) 3 (2005): 41-55.

Albrecht, Glenn, Gina-Maree Sartore, Linda Connor, Nick Higginbotham, Sonia Freeman, Brian Kelly, Helen Stain, Anne Tonna, and Georgia Pollard. "Solastalgia: The Distress Caused by Environmental Change". Australian Psychiatry 15 (2007): 95-8.

Batchelor, Tom. "Climate Apartheid. Rich people to buy their way out of the environmental crisis while poor suffer, warns UN". 2019. Retrieved in October 2020, available at https://www.independent.co.uk/environment/climate-changecrisis-rich-poor-wealth-apartheid-environment-un-report-a8974231.html.

Bauman, Zygmunt. Liquid Modernity. Cambridge: Polity Press, 2000.

Beck, Ulrick. The Risk Society. Cambridge: Polity Press, 1992.

Beck, Urick and Wolfgang Bonss. Die Modernisierung der Moderne. Frankfurt am Main: Suhrkamp, 2001.

Clayton, Susan. "Climate Anxiety: Psychological Responses to Climate Change". Journal of Anxiety Disorders 74 (2020).

Collins, Randall. "Social Distancing as a Critical Test of the Micro-Sociology of Solidarity". American Journal of Cultural Sociology 8 (2020): 477-97.

Cunsolo, Ahslee and Karen Landman eds. Mourning Nature. Hope at The Heart of Ecological Loss and Grief. Montreal: McGill-Queen's University Press, 2017.

Cunsolo, Ashlee and Neville R. Ellis. "Ecological grief as a mental health response to climate change-related loss". Nature Climate Change 8, no. 4 (2018): 275-81.

Crutzen, Paul. J. and Eugene F. Stoermer. "The Anthropocene". Global Change Newsletter 41 (2000): 17-8.

Davies, Fred. Yearning for Yesterday. A Sociology of Nostalgia. New York: Free Press, 1979.

Doka, Kenneth J. Disenfranchised Grief: Recognizing Hidden Sorrow. Lexington MA: Lexington Books/D. C. Heath \& Co., 1989.

-----. “Disenfranchised Grief”. Bereavement Care 18, no. 3 (1999): 37-9. 
Drummond, John J. “Anger and Indignation”. In Emotional Experiences. Ethical and Social Significance, John J. Drummond and Sonia Rinofner-Kreidl eds., 15-31. London: Rowman and Littlefield International, 2017.

Fraser, Nancy. "Contradictions of Capital and Care". New Left Review 100 (2016): 99-117.

-----. "Climates of Capital. For a Trans-Environmental Eco-Socialism". New Left Review 127 (2021): 94-127.

Fuchs, Thomas. "Presence in Absence. The Ambiguous Phenomenology of Grief". Phenomenological Cognitive Science 17 (2018): 43-63.

Giddens, Anthony. Modernity and Self-Identity: Self and Society in the Late Modern Age. Cambridge: Polity Press, 1991.

Hess, Ursula. "Anger is a positive emotion". In The Positive Side of Negative Emotions, W. G. Parrott ed., 55-75 New York: Guilford Press, 2014.

Hume, David. A Treatise of Human Nature. Oxford: Oxford University Press, 1978.

Jakoby, Nina R. "The Self and Significant Others: Toward a Sociology of Loss". Illness, Crisis and Loss 23, no. 2 (2015): 110-28.

Jordan, Joanne Catherine. "Swimming Alone? The Role of Social Capital in Enhancing Local Resilience to Climate Stress: A Case Study from Bangladesh”. Climate and Development 7, no. 2 (2015): 110-123.

Lélé, Sharachchandra M. "Sustainable Development: A Critical Review". World Development 19, no. 6 (1991): 607-21.

Lichtblau, Klaus. "Sociology and the Diagnosis of the Times, or: the Reflexivity of Modernity”. Theory, Culture and Society 12, no. 1 (1995): 25-52.

Lindemann, Erich. "The Symptomatology and Management of Acute Grief". American Journal of Psychiatry 101 (1944): 141-48.

Lipovetsky, Gilles. Hypermodern Times. Cambridge: Polity Press, 2005.

Lyotard, Jean-Francois. La condition postmoderne: Rapport sur le savoir. Paris: Éditions de Minuit, 1981.

MacSuibhne, Seamus P. "What Makes 'a New Mental Illness'?: The Cases of Solastalgia and Hubris Syndrome". Cosmos and History: The Journal of Natural and Social Philosophy 5, no. 2 (2009): 210-25.

Majeed, Haris and Jonathan Lee. "The Impact of Climate Change on Youth Depression and Mental Health". The Lancet 1 (2017): 94-5. 
Moore, Melissa M. and Janet Z. Yang. "Using Eco-Guilt to Motivate Environmental Behavior Change”. Environmental Communication 14, no. 4 (2020): 522-36.

Neate, Rupert. "Super-rich jet off to disaster bunkers amid coronavirus outbreak". 2020. Retrieved in October 2020, available at https://www.theguardian.com/world/2020/mar/11/disease-dodging-worriedwealthy-jet-off-to-disaster-bunkers? fbclid=IwAR0BuHhiOTjpQ8XU4iCTDiqHqhB1YCXCLdkLX7yKmMmH0p4J 41W1qyVw2sk.

Norgaard, Kari M. "People Want to Protect Themselves a Little Bit: Emotions, Denial, and Social Movement Nonparticipation”. Sociological Inquiry 76, no. 3 (2006): 372-96.

O’Neil, Saffron and Sophie Nicholson-Cole. “"Fear Won’t Do It'. Promoting Positive Engagement with Climate Change through Visual and Iconic Representations". Science Communication 30, no. 3 (2009): 355-79.

Petersen, Anders and Michael H. Jacobsen. "Grief - The Painfulness of Permanent Human Absence". In Emotions, Everyday Life and Sociology, Michael H. Jacobsen ed., 191-208. London: Routledge, 2018.

Petersen, Anders. "Når klimaets tilstand gør ondt: Følelser i klimakrisens tid [When the Conditions of the Climate Are Hurting: Feelings in the Age of the Climate Crisis]”. In Det går til Helvete. Eller?: Om kjcerlighet, sorg og raseri i natur- og klimakrisens tid, Knut Ivar Bjørlykhaug and Arne Johan Vetlesen eds., 91-106. Oslo: Dinamo Forlag, 2020.

Ratcliffe, Matthew. "Grief and Phantom Limbs: A Phenomenological Comparison". 2018. Retrieved in February 2021, available at https://www.researchgate.net/profile/Matthew_Ratcliffe2/publication/ 332282215_Grief_and_phantom_limbs/links/5d29c8f6a6fdcc2462daf1f1/Griefand-phantom-limbs.pdf.

Robson, Patricia and Tony Walter. "Hierarchies of Loss: A Critique of Disenfranchised Grief”. Omega 66, no. 2 (2012-2013): 97-119.

Roeser, Sabine. "Risk Communication, Public Engagement, and Climate Change: A Role for Emotions". Risk Analysis 32, no. 6 (2012): 1033-40.

Rosa, Hartmut. Acceleration and Alienation. Malmø: NSU-Press, 2010.

-----. Resonance. A Sociology of the Relationship to the World. Cambridge: Polity Press, 2019. 
-----. The Uncontrollability of the World. Cambridge: Polity Press, 2020.

Rose, Nikolas. Our Psychiatric Future. Cambridge: Polity Press, 2019.

Sartre, Jean-Paul. Being and Nothingness. London: Philosophical Library, 1956.

Simmel, Georg. "The Sociology of Sociability". American Journal of Sociology 55, no. 3 (1949): 254-61.

The Care Collective. The Care Manifesto. The Politics of Interdependence. New York: Verso, 2020.

\begin{abstract}
About the author
Anders Petersen. Associate Professor of Sociology at the Department of Sociology and Social Work in Aalborg University (Aalborg, Denmark). He received a Ph.D at the University of Örebro in Sweden, and has studied Social Sciences and Sociology in Aalborg University and Goldsmiths College, University of London. His research is particularly concerned with sociological theory and contemporary psychological malaises. He has, among others, published articles and books on depression, diagnostic culture, grief, death, the climate crisis, happiness, recognition, individualism and perceptions of self. E-mail: apt@socsci.aau.dk.
\end{abstract}

